If you want to be a research biologist, a degree can be a hindrance, according to Professor Kenneth Mellanby, former Director of Monks Wood Experimental Station. Addressing the British Association, he said that promising school leavers now stand a better chance than the average graduate of a career in biological research.

The career structure of research institutes, especially those financed by government, favoured two types of scientific worker. There would always be room for the first-class graduate with a higher degree, although the number of such vacancies, already small, may decline even further as the Fulton proposals improving promotion prospects for junior staff come into force. At the other end of the scale, said Professor Mellanby, most Directors prefer bright school-leavers for junior research and technical posts, and there is no lack of these wishing to take up a biological career.

Although Professor Mellanby acknowledges the situation he is far from happy about it. If good graduates and postgraduates cannot get jobs in research the quality of research will inevitably suffer, he said. In his view, the scientist who had risen through the ranks, admirable though he or she might be at the job, would not have a similar capability for research.

Professor Mellanby's impression was of a "great over-production of graduates and doctors and high unemployment". But, in fact, after an initial disappointment, the biology graduate usually found a congenial niohe in a variety of other occupations.

But industries requiring graduates with a specialised applied training such as chemical engineering or metallurgy are experiencing a shortage of trained graduates to fill an ever increasing number of jobs. In 1974 the number of

applications for degree places in chemical engineering dropped dramatically at a time when the demand for chemical engineers had suddenly taken a rapid upwards turn. The number of jobs in chemical engineering advertised in the Institution of Chemical Engineering's 'Diary' had dropped from 742 in 1969 to 178 in 1972 but had risen to 405 in 1973 and in 1974 was

\section{Job crisis or manpower crisis?}

by Eleanor Lawrence

expected to top the 800 mark, saic Dr David Sharp of the Institution.

Was this decline in graduate applications simply a result of straightened job prospects during the early 1970s? Dr Sharp is convinced that the cause lies much deeper; physical science teaching at secondary school level is neither inspiring enough nor of sufficiently high quality to encourage the school child in this sort of career he said. No graduates with engineering backgrounds went back into teaching at secondary school level, so that schools careers officers were completely ignorant of courses and carcer prospects. The tiny proportion of physics graduates entering teaching also worried Dr L. Cohen of the Institute of Physics. Chemistry may fare better, as in 1973 about $15 \%$ of first degree chemistry graduates entered teacher training.

Industry would no doubt find ways of getting round the specific manpower shortage, said Dr Sharp. The slack a class. And it was pointed out more would probably be taken up by people than once that other graduates had trained in related disciplines such as always been in the position of having chemistry. But a shortage of metallur- to find work unrelated to their specific gists could hold up programmes of training. present financial situation, the univer-

\section{Only connect \\ by Gillian Boucher}

SCIENCE undergraduates lack the critical training needed to see their subject in the broader context of society or even of science as a whole. This is the thread running through the many experimental curricula and proposals for change described during a week-long session at the BA. Motives and methods varied widely but the courses described fitted into two broad categories: traditional science taught alongside "science studies' (the salad principle); and the interdisciplinary science course (the porrage or porridge principle).

Dr David Edge, Director of the Science Studies Unit in the University of Edinburgh, described the alternatives to the traditional British subject- oriented course. First, a course aiming to fit the student for a carcer. This might entail teaching an additional subject like economics, or a skill like decision making. Second, the course cculd be more geaned to the personal needs of the student who may feel that his development requires more than a single science taught in a particular way. Third, courses could aim to make students of more immediate use to society as a whole.

There was complete agreement that the traditional science courses and subjects should remain on the curriculum. But there was strong support for the provision of alternative courses. The commonest reasons given were the interests of the student's future career and of society, the two often being treated as identical. In the eyes of Pro- metal reclamation and recycling said Institute of Metallurgists, as university departments of metallurgy declined and in some cases disappeared.

So the "job crisis" tends to look rather different depending on where one is standing. A picture emerges, not so much of a crisis, but of increasing diversification amongst science graduates. Fiveryone was agreed that, except in the special cases of the applied fields, there certainly has been a drop in jobs which use scientific training directly. Some parts of industry had increased their recruiting this year, but in the sities and the scientific civil service would take fewer and fewer people.

But the patterns of first year employment seem to be evolving to meet the changes quite successfully, though how much individual disappointment is hidden behind the statistics is hard to ell.

Diversification is not necessarily a forced choice. Salaries of professional scientists compare very unfavourably with their contemporaries in management or administration in both industry and the civil service. Dr R. E. Parker of the Royal Institute of Chemistry produced comparisons of salaries between research, technical and management grades in the chemical industry which clearly direct the financially ambitious away from pure science.

Employment or lack of it amongst science graduates must be set in the wider economic context. Dr Cohen emphasised that absolute unemployment amongst science graduates was till lower than amongst graduates as

fessor F. R. Bradbury of the University of Stirling the "Advancement of Science' was no longer so much in the public interest as it had been when the British Association was founded: instead, students should learn to manipulate the scientific knowledge already attained and apply it to the messy problems of real life.

Those who preach interdisciplinarity are adamant that the porridge should be smooth. It is not enough to teach several subjects side by side as in a joint honours degree or the old general degrees. It is not even enough to allow the student a great deal of choice between course units. Integration requires a totally new approach-an emphasis on the connections between subjects, which will lead to the subjects themselves being taught differently. To 